\title{
EEFECT OF IRRIGATION AT DIFFERENT SOIL MOISTURE DEPLETION LEVELS AND RATES OF POTASSIUM FERTILIZATION ON PRODUCTIVITY AND WATER USE EFFICIENCY OF SUGAR BEET \\ El-Bably, A.Z. ${ }^{1}$ and N.M.M. Awad ${ }^{2}$ \\ 1- Soil, Water and Environment Res. Inst. A. R. C., Giza, Egypt \\ 2- Sugar Crops Res. Inst., Agric. Res. Center, Giza, Egypt
}

ABSTRACT

Two field experiments were conducted at Sakha Agricultural Research Station, Kafr El-Sheikh governorate during the two successive seasons 2005/2006 and $2006 / 2007$ to study the effect of irrigation after $40 \%, 60 \%$ and $80 \%$ depletion of available soil moisture (ASMD), and three potassium rates i.e. 0,24 and $48 \mathrm{~kg}$ $\mathrm{K}_{2} \mathrm{O} / \mathrm{fed}$. on sugar beet yield and water use efficiencies. A split plot design with four replications was used. Irrigation treatments occupied the main plots, while potassium rates arranged in sub-plots.

Results showed that increasing soil moisture depletion from $40 \%$ to $80 \%$ significantly decreased root diameter by $2.9 \%$, root weight/plant by $6.8 \%$, top yield/fed. by $4.6 \%$, root yield/fed. by $4.1 \%$ and sugar yield/fed. by $10.0 \%$. On the other hand, root length, total soluble solids and sucrose percentage were increased by $16.1 \%, 1.2 \%$ and $1.20 \% \%$, respectively. Increasing potassium application up to 48 $\mathrm{kg} \mathrm{K}{ }_{2} \mathrm{O} / \mathrm{fed}$. significantly increased root length, root diameter, root weight/plant, fresh top and root yields/fed. by $2.2 \%, 3.0 \%, 1.7 \%, 4.5 \%$ and $6.3 \%$, respectively, compared to the control treatment.

Seasonal water consumptive use values were $61.0 \mathrm{~cm}, 56.19 \mathrm{~cm}$ and $46.38 \mathrm{~cm}$ for irrigation after depletion of $40 \%, 60 \%$ and $80 \%$ of available water, respectively. In addition increasing $\mathrm{K}$-rates up to $48 \mathrm{~kg} \mathrm{~K} \mathrm{~K}_{2} \mathrm{O} / \mathrm{fed}$. slightly increased seasonal water use.

Seasonal irrigation water applied values were $68.28 \mathrm{~cm}\left(2867.8 \mathrm{~m}^{3} / \mathrm{fed}\right.$.), distributed on eight irrigations, $62.08 \mathrm{~cm}\left(2607.4 \mathrm{~m}^{3} / \mathrm{fed}\right.$.), distributed on seven irrigations and $55.07 \mathrm{~cm}\left(2312.9 \mathrm{~m}^{3} / \mathrm{fed}\right.$.), distributed on six irrigations, for irrigation after $40 \%, 60 \%$, and $80 \%$ of available soil moisture depletion, respectively.

Water use efficiencies values for both root or sugar yields increased as soil moisture depletion increased. While water use efficiencies for both root or sugar yields significantly increased as potassium rate increased up to $48 \mathrm{~kg} \mathrm{~K} \mathrm{~K}_{2} \mathrm{O} / \mathrm{fed}$.

The mean percentage values of water extracted from the upper $30 \mathrm{~cm}$ soil layer were $76.36,71.78$ and $65.18 \%$ when sugar beet plants irrigated at $40 \%, 60 \%$ and $80 \%$ of ASMD, respectively,

A linear slop indicated that each one $\mathrm{cm}$ of water applied increased the productivity of root and sugar yields by 74 and $15.7 \mathrm{~kg} / \mathrm{fed}$. In addition irrigation water applied is strongly positively correlated with roots yield and negatively to water use efficiencies.

Therefore, when water is becoming a limited factor, irrigation at $80 \%$ of ASMD could be applied for saving $17.8 \%$ of irrigation water against $4.1 \%$ and $3.4 \%$ reduction in the root and sugar compared to irrigation at $40 \%$ of ASMD.

\section{INTRODUCTION}

Sugar beet (Beta vulgaris L.) is considered to be the second source for sugar production in Egypt. The importance of this crop comes from its ability to grow in the new reclaimed lands. Sugar beet is also adapted to a 
wide range of climatic conditions. It is tolerant to soil salinity and soil water stress (Hills et al., 1990). Increasing sugar production from land unit area is considered one of the important national targets in Egypt to minimize sugar gab between production and consumption. Great efforts are being done to increase sugar production by proper utilization of the irrigation water and increase the efficiency of added potassium fertilization. So, water and potassium fertilization are among the most important factors affecting sugar beet production. El-Sabbagh et al. (2003) revealed that increasing soil moisture depletion from $40-45 \%$ to $80-85 \%$ of available soil moisture deletion levels significantly decreased root diameter, root weight/plant, top yield/fed., root yield and sugar yield. They also found that seasonal water consumptive use values were $60.90 \mathrm{~cm}, 55.43 \mathrm{~cm}$ and $46.28 \mathrm{~cm}$ for irrigation at the depletion of $40-45 \%, 60-65 \%$, and $80-85 \%$ of available soil water content, respectively. El-Zayat (2000) concluded that irrigating sugar beet plants at $75 \%$ soil moisture depletion significantly decreased root diameter, top, root and sugar yields/fed. However, root length and gross sugar content significantly decreased with increasing the available soil moisture content in the root zone. He added also that juice purity percentage was not affected by irrigation treatments. Mean seasonal consumptive use values were 61.96, 56.17 and $40.12 \mathrm{~cm}$ for the 33,55 and $75 \%$ soil moisture depletion, respectively. Water use efficiency for root or white sugar production were increased with increasing soil moisture depletion up to $75 \%$. Semaika and Rady (1988) indicated that the highest values of fresh weight, length and diameter of roots were obtained when plants were subjected to $40 \%$ ASMD. Abou-Ahmed (2003) found that irrigation intervals of three weeks significantly produced the highest top, roots, and sugar yields to be 7.61, 23.04 and 3.84 t/fed., respectively. However, by prolonging irrigation intervals from three to four and five weeks significantly increased root length. Brown et al. (1987) reported that when sugar beet was exposed to both early and late drought stress, it had a higher sugar content in the root, although there was a reduction in growth of sugar beet and its productivity (root and sugar yields). Saif et al. (1997) indicated that the highest root, top and sugar yields as well as juice quality and sucrose percentage were attained by irrigation every 21 days. Shams EI-Din (2000) observed that the highest sugar beet yield was obtained with irrigation at field capacity to a depth of $30 \mathrm{~cm}$. Also, he found that the highest value of seasonal consumptive use was $60.03 \mathrm{~cm}$ gained from watering at field capacity plus $5 \%$. On the other hand, irrigation at field capacity minus $5 \%$ gave the highest water use efficiency for both root and sugar yields. Shehata et al. (2000) found that under severe water stress $(25 \%$ of the maximum available water) diameter, fresh weight of roots was decreased comparing with $100 \%$ of available water. However, a gradual increase in root length, total soluble solids and sucrose percentage were obtained by increasing water stress levels. On the other hand, either purity percentage or sugar yield was lowered by drought.

Potassium plays an important role in physiological processes in the plant such as translocation of sugars and carbohydrates. Many investigators proved that sugar beet yield and quality are greatly affected by applied levels of potassium fertilizer. Basha (1994) observed that increasing rate of $\mathrm{K}$ from 
25 to $100 \mathrm{~kg} \mathrm{~K}$ O/fed. significantly increased root length and diameter, top, root and sugar yields/fed., sucrose and purity percentages. El-Essawy (1996) reported that increasing $\mathrm{K}$ rate from zero to $48 \mathrm{~kg} \mathrm{~K} \mathrm{O} / \mathrm{fed}$. significantly increased length, diameter, root weight/plant, root, top and sugar yields/fed. $\mathrm{He}$ added that sucrose and purity percentages were not significantly affected by the applied levels of K fertilizer. Selim and El-Ghinbihi (1999) found that increasing $\mathrm{K}$ increased root, top and sugar yields/fed. Also, they noticed that $\mathrm{K}$ significantly increased the sucrose content but juice purity was decreased. Khalifa et al. (2000) showed that increasing K-rates up to $45 \mathrm{~kg} \mathrm{~K} / \mathrm{fed}$. significantly increased root length and diameter, root and shoot yields/fed. On the contrary, purity percentage was slightly decreased with increasing Krates. El-Shafai (2000) indicated that increasing K-level from zero to $48 \mathrm{~kg}$ $\mathrm{K}_{2} \mathrm{O} / \mathrm{fed}$. positively increased root fresh weight/plant, sugar yield and sucrose percentage. Root yield insignificantly increased as K-level increased up to 48 $\mathrm{K}_{2} \mathrm{O} / \mathrm{fed}$. Purity percentage was not significantly affected by K-levels. Khalil et al. (2001) indicated that potassium fertilization showed slight increase in sucrose, total soluble solids and purity.

The aim of the current work is to investigate the effect of irrigation at different soil moisture levels and potassium fertilizer rates on the productivity, juice quality and soil-water relations of sugar beet.

\section{MATERIALS AND METHODS}

This investigation was conducted at Sakha Agricultural Research Station, Kafr El-Sheikh, Governorate during the two successive seasons $2005 / 2006$ and $2006 / 2007$. The soil of the experimental sites was clayey in texture. Water table level using observation well was $122 \mathrm{~cm}$. The average of the electrical conductivity and $\mathrm{pH}$ value of the soil in the saturated soil paste were $2.33 \mathrm{dS} / \mathrm{m}$ and 8.15 , respectively. The level of available $\mathrm{K}$ was 290 ppm, according to method of Black et al. (1985).

A split-plot design with four replications was followed. The main plots were occupied to irrigation treatments; i.e., 40, 60 and $80 \%$ depletion in available soil water content (ASMD). The sub-plot were assigned for three potassium rates i.e., 0,24 and $48 \mathrm{~kg} \mathrm{~K}{ }_{2} \mathrm{O} / \mathrm{fed}$. in the form of $\mathrm{K}$-sulphate $(48 \%$ $\mathrm{K}_{2} \mathrm{O}$ ). Sub-plot area was $42 \mathrm{~m}^{2}$ including 10 ridges, $7 \mathrm{~m}$ long and $60 \mathrm{~cm}$ apart. Plots were isolated by ditches of $1.5 \mathrm{~m}$ in width to avoid lateral movement of water. The preceding crop was maize in both seasons.

Sowing process took place on November $10^{\text {th }}$ and $8^{\text {th }}$ in the two seasons, respectively. Sugar beet seeds cv. Raspoly were planted in hills 20 $\mathrm{cm}$ apart on one side of ridges. Plants were thinned to one plant/hill after 40 days from sowing. Phosphatic fertilizer in the form of calcium superphosphate $\left(15.5 \% \mathrm{P}_{2} \mathrm{O}_{5}\right)$ at rate of $30 \mathrm{~kg} \mathrm{P}_{2} \mathrm{O}_{5} / \mathrm{fed}$. was applied during tillage operation. Potassium fertilizer with mentioned rates and nitrogen with the recommended dose $90 \mathrm{~kg} \mathrm{~N} / \mathrm{fed}$. as urea $(46.5 \% \mathrm{~N})$ were applied just before the first irrigation after thinning. Other cultural practices were carried out as recommend.

Plants were harvested, 200 days after sowing. Ten guarded plants were taken randomly from each plot for subsequent measurements i.e. 1) root length in $\mathrm{cm}, 2$ ) root diameter in $\mathrm{cm}, 3$ ) root weight in $\mathrm{gm}$, in addition to 
quality parameters i.e. 4) total soluble solids (TSS\%) was determined by using hand refractometer, 5) sucrose percentage, 6) purity of juice percentage and sugar yield. Sucrose percentage was determined by using saccharometer according to LeDocte (1927), and purity of juice percentage was calculated according to the following equation.

Juice purity $\%=$ sucrose $\% \times 100 /$ T.S.S. $\%$

Sugar yield, was calculated according the following equation:

Sugar yield (ton/fed.) = root fresh weight yield (ton/fed.) $x$ sucrose $\%$.

The five guarded ridges from the middle of each plot were harvested to determine both top and root fresh weight yields/fed.

Data were subjected to the combined analysis as described by Snedecor and Cochran (1980). The treatment means were compared according to Duncan's multiple range test (Duncan, 1955).

Sakha meteorological station data, during 2005/06 and 2006/07 seasons, were recorded. Meteorological data including air temperature, relative humidity, and rainfall distribution are presented in Table 1.

Table (1): Sakha meteorological data of Agricultural Research station during $2005 / 06$ and $2006 / 07$ seasons.

\begin{tabular}{|c|c|c|c|c|c|c|c|c|c|c|c|c|c|c|}
\hline \multirow[t]{3}{*}{ Seasons } & \multicolumn{6}{|c|}{$2005 / 06$} & \multirow{3}{*}{ 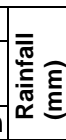 } & \multicolumn{6}{|c|}{$2006 / 07$} & \multirow{3}{*}{ 㷰 } \\
\hline & \multicolumn{3}{|c|}{$\begin{array}{c}\text { Air } \\
\text { temperature }{ }^{\circ} \mathrm{C}\end{array}$} & \multicolumn{3}{|c|}{$\begin{array}{c}\text { Relative } \\
\text { humidity (\%) }\end{array}$} & & \multicolumn{3}{|c|}{$\begin{array}{c}\text { Air } \\
\text { temperature }{ }^{\circ} \mathrm{C}\end{array}$} & \multicolumn{3}{|c|}{$\begin{array}{c}\text { Relative } \\
\text { humidity (\%) }\end{array}$} & \\
\hline & Max. & Min. & Mean & Max. & Min. & Mean & & Max. & Min. & Mean & Max. & Min. & Mean & \\
\hline Nov. & 24.2 & 10.6 & 17.4 & 77.3 & 56.0 & 66.7 & 8.3 & 23.5 & 8.9 & 16.2 & 77.0 & 58.6 & 67.8 & 3.2 \\
\hline es & 20.0 & 7.0 & 13.5 & 86.5 & 60.0 & 73.3 & 8.8 & 19.7 & 4.5 & 12.1 & 82.0 & 62.2 & 72.1 & 10.0 \\
\hline & 18.8 & 5.1 & 12.0 & 86.0 & 61.0 & 73.5 & 7.6 & 18.7 & 4.1 & 11.4 & 87.0 & 58.5 & 72.8 & 17.5 \\
\hline eb. & 22.0 & 6.0 & 13.0 & 93.4 & 66.0 & 79.7 & 18.0 & 21.6 & 5.6 & 13.6 & 95.4 & 67.6 & 81.5 & 44.1 \\
\hline Mar. & 22.6 & 7.0 & 14.8 & 80.0 & 51.2 & 65.6 & 2.1 & 22.0 & 5.8 & 13.9 & 79.2 & 51.7 & 65 & 9.0 \\
\hline Apr. & 27.0 & 9.5 & 18.3 & 81.0 & 47.0 & 64.0 & 24.8 & 25.3 & 7.5 & 16.4 & 80.5 & 49.5 & 65.0 & 11.4 \\
\hline May & 28.5 & 11.6 & 20.1 & 79.3 & 45.0 & 62.2 & 0.0 & 28.3 & 11.1 & 19.7 & 78.9 & 45.1 & 62.0 & 0.0 \\
\hline
\end{tabular}

\section{Soil-water relations:}

Soil moisture content was gravimetrically determined in soil samples taken from consecutive depths of $15 \mathrm{~cm}$ down to a depth of $60 \mathrm{~cm}$. Soil samples were also collected just before each irrigation, 48 hours after irrigation and at harvest time. Irrigation water was applied when the moisture content reached the desired available soil moisture in each treatment. Field capacity, Permanent wilting point and bulk density were executed according to Black et al. (1985) to a depth of $60 \mathrm{~cm}$. Available soil moisture was calculated by subtracting wilting point from field capacity. The average values are presented in Table (2).

Table (2): Soil moisture constants for soil of the experimental site.

\begin{tabular}{|c|c|c|c|c|}
\hline $\begin{array}{c}\text { Soil depth } \\
\text { (cm) }\end{array}$ & $\begin{array}{c}\text { Field } \\
\text { capacity (\%) }\end{array}$ & $\begin{array}{c}\text { Wilting } \\
\text { point (\%) }\end{array}$ & $\begin{array}{c}\text { Bulk } \\
\text { density } \mathbf{( g / \mathbf { c m } ^ { 3 }} \text { ) }\end{array}$ & $\begin{array}{c}\text { Available soil } \\
\text { water \% }\end{array}$ \\
\hline $0-15$ & 46.61 & 25.72 & 1.10 & 20.89 \\
$15-30$ & 40.17 & 23.91 & 1.16 & 16.26 \\
$30-45$ & 37.15 & 22.33 & 1.21 & 14.82 \\
$45-60$ & 35.14 & 21.43 & 1.30 & 13.71 \\
\hline
\end{tabular}


III. Soil-water relations:

1. Water consumptive use (WCU):

Water consumptive use was calculated using the following equation (Hansen et al., 1979).

$\mathrm{CU}=\sum_{\mathrm{i}=1}^{\mathrm{i}=4} \mathrm{Di} \times \mathrm{D}_{\mathrm{bi}} \times \mathrm{PW}_{2}-\mathrm{PW}_{1} / 100$

Where:

$\mathrm{CU}=$ water consumptive use $(\mathrm{cm})$ in the effective root zone $(60 \mathrm{~cm}$.

$\mathrm{D}_{\mathrm{i}} \quad=$ soil layer depth $=15 \mathrm{~cm}$.

$D_{b i}=$ soil bulk density, $\left(\mathrm{g} / \mathrm{cm}^{3}\right)$ for this depth.

$\mathrm{PW}_{1}=$ soil moisture percentage before irrigation.

$\mathrm{PW}_{2}$ = Soil moisture percentage, 48 hours after irrigation.

$\mathrm{i}=$ Number of soil layer $(15 \mathrm{~cm})$.

\section{Irrigation water applied (IWA):}

Submerged flow orifice with fixed dimension was used to measure the amount of water applied, as the following equation (Michael, 1978).

$\mathrm{Q}=\mathrm{CA} \sqrt{2 \mathrm{gh}}$

Where:

$\mathrm{Q}=$ discharge through orifice, $(1 / \mathrm{sec})$.

C = coefficient of discharge, (0.61).

A $=$ cross-sectional area of the orifice, $\mathrm{cm}^{2}$.

$\mathrm{g}=$ acceleration due to gravity, $\mathrm{cm} / \mathrm{sec}^{2}{ }^{2}\left(981 \mathrm{~cm} / \mathrm{sec} .^{2}\right)$.

$\mathrm{h}=$ pressure head, causing discharge through the orifice, $\mathrm{cm}$.

3.Crop water use efficiency (CWUE):

It was calculated according to Michael (1978).

WUE $=\mathrm{Y} / \mathrm{CU}$

Where:

$\mathrm{Y}=$ root yield or sugar yield $(\mathrm{kg})$.

$\mathrm{CU}=$ seasonal water consumptive use $\left(\mathrm{m}^{3}\right)$.

4. Field water use efficiency (FWUE): was calculated according to Jensen (1983).

FWUE $=\frac{Y}{I W R}$

Where:

$\mathrm{Y} \quad=$ root yield in $\mathrm{kg}$

IWR = seasonal irrigation water applied in $\mathrm{cm}$.

5.Soil moisture extraction pattern (SMEP):

It was calculated according to the following equation, (Hansen et al., 1979). SMEP $=$ CU (layer) $\times 100 / C U$ (seasonal)

Where:

$\mathrm{CU}$ (layer) = sum of extracted soil moisture in each soil layer $(15 \mathrm{~cm})$.

$\mathrm{CU}$ (seasonal) = total sum of moisture extracted in all soil layers $(60 \mathrm{~cm})$.

\section{RESULTS AND DISCUSSIONS}

\section{Yield and its components:}

Data presented in Table (3) revealed that as the soil moisture stress increased significant and gradual decrease in all studied traits of sugar beet 
(except for root length) were recorded. The highest reduction was $2.9 \%$. $6.8 \%, 4.6 \%$ and $4.1 \%$ for root diameter, root weight/plant, top and root yields/fed., respectively, resulted from irrigation at $80 \%$ of ASMD compared with irrigation at $40 \%$ of ASMD.

At the same time, the results showed that there were no significant differences in root yield between irrigation after $40 \%$ and $60 \%$ of ASMD. The decrease in root yield and its characteristics might be due to the reduction in both metabolic products and transport of photosynthetic assimilates under the water stress condition. On the other hand, when sugar beet plants were exposed to water stress, root length was significantly enhanced deeply, Simpson (1981) explained that lengthening the roots in the soil was to exploit the deeply stored soil moisture to avoid drought stress damage. This result is in accordance with those reported by Gaber et al. (1986), Saif et al. (1997), El-Zayat (2000), Abou-Ahmed (2003) and El-Sabbagh et al. (2003).

Table (3): Mean values of root characteristics, fresh top and root yield of sugar beet as affected by soil moisture depletion and different rates of potassium fertilizer in the combined analysis over the two growing seasons.

\begin{tabular}{|c|c|c|c|c|c|}
\hline Treatments & $\begin{array}{c}\text { Root } \\
\text { length }(\mathrm{cm})\end{array}$ & $\begin{array}{c}\text { Root } \\
\text { diameter } \\
(\mathbf{c m})\end{array}$ & $\begin{array}{l}\text { Fresh } \\
\text { root/plant } \\
\text { (kg) }\end{array}$ & $\begin{array}{l}\text { Fresh top } \\
\text { yield } \\
\text { (ton/fed.) }\end{array}$ & $\begin{array}{c}\text { Fresh root } \\
\text { yield } \\
\text { (ton/fed.) }\end{array}$ \\
\hline $\begin{array}{l}\text { Irrigation treatments: } \\
40 \% \text { ASMD } \\
60 \% \text { ASMD } \\
80 \% \text { ASMD }\end{array}$ & $\begin{array}{l}22.45 \mathrm{~b} \\
25.88 \mathrm{a} \\
26.06 \mathrm{a}\end{array}$ & $\begin{array}{l}9.32 \mathrm{a} \\
9.18 \mathrm{~b} \\
9.05 \mathrm{c}\end{array}$ & $\begin{array}{l}1.058 \mathrm{a} \\
1.029 \mathrm{~b} \\
0.986 \mathrm{c}\end{array}$ & $\begin{array}{l}7.15 \mathrm{a} \\
7.03 \mathrm{~b} \\
6.82 \mathrm{c}\end{array}$ & $\begin{array}{l}23.72 \mathrm{a} \\
23.39 \mathrm{a} \\
22.74 \mathrm{~b}\end{array}$ \\
\hline 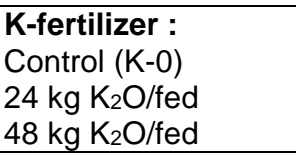 & $\begin{array}{l}24.52 \mathrm{~b} \\
24.82 \mathrm{~b} \\
25.05 \mathrm{a}\end{array}$ & $\begin{array}{l}9.03 \mathrm{~b} \\
9.22 \mathrm{a} \\
9.30 \mathrm{a} \\
\end{array}$ & $\begin{array}{l}1.022 \mathrm{c} \\
1.031 \mathrm{~b} \\
1.039 \mathrm{a}\end{array}$ & $\begin{array}{l}6.84 \mathrm{c} \\
7.01 \mathrm{~b} \\
7.15 \mathrm{a} \\
\end{array}$ & $\begin{array}{l}22.51 \mathrm{c} \\
23.42 \mathrm{~b} \\
23.92 \mathrm{a}\end{array}$ \\
\hline $\begin{array}{l}\text { Interactions: } \\
\text { Irrigation } \mathrm{x} \text { season } \\
\mathrm{K} \text { x season } \\
\text { Irrigation } \times \mathrm{K} \\
\text { Irrig. } \mathrm{x} \mathrm{K} \text { x season }\end{array}$ & $\begin{array}{l}\text { N.S } \\
\text { N.S } \\
\text { N.S } \\
\text { N.S }\end{array}$ & $\begin{array}{l}\text { N.S } \\
\text { N.S } \\
\text { N.S } \\
\text { N.S }\end{array}$ & $\begin{array}{l}\text { N.S } \\
\text { N.S } \\
\text { N.S } \\
\text { N.S }\end{array}$ & $\begin{array}{l}\text { N.S } \\
\text { N.S } \\
\text { N.S } \\
\text { N.S }\end{array}$ & $\begin{array}{l}\text { N.S } \\
\text { N.S } \\
\star * \\
\text { N.S }\end{array}$ \\
\hline
\end{tabular}

Means designated by the same letter at each cell are not significantly different at $5 \%$ leve according to Duncan's multiple range test.

N.S.: indicate not significant

Regarding potassium effect, data showed that increasing potassium application up to $48 \mathrm{~kg} \mathrm{~K}{ }_{2} \mathrm{O} / \mathrm{fed}$. had significantly increased root length, root diameter, root weight/plant, fresh top and root yields/fed. by $2.2 \%, 3.0 \%$, $1.7 \%, 4.5 \%$ and $6.3 \%$, respectively, compared to the control treatment. This result could be attributed to the important role of potassium in physiological processes in the plant such as translocation of sugars and carbohydrates. Similar results obtained by Basha (1994) and Khalifa et al. (2000).

Insignificant effect was detected with any of the interactions between the two variables studied except irrigation and potassium rates on roots yield $\mathrm{t} / \mathrm{fed}$. as shown in Table 3.

Interaction between irrigation treatments and potassium rates: 
It is obvious form Table 4 that the highest mean values of root yield was obtained from irrigation at $40 \%$ of ASMD that fertilized with $48 \mathrm{~kg}$ $\mathrm{K}_{2} \mathrm{O} / \mathrm{fed}$. However, the lowest value resulted from irrigation at $80 \%$ of ASMD without potassium fertilizer.

Table (4): Interaction between irrigation treatments and potassium rates on root yield, over both growing seasons.

\begin{tabular}{|c|c|c|c|}
\hline Irrigation & \multicolumn{3}{|c|}{ Root yield $t / f e d$} \\
\hline treatments & $40 \%$ ASMD & $60 \%$ ASMD & $80 \%$ ASMD \\
\hline $\begin{array}{l}\text { K-fertilizer : } \\
\text { Control (K-0) } \\
24 \mathrm{~kg} \mathrm{~K} \mathrm{O} / \mathrm{fed} \\
48 \mathrm{~kg} \mathrm{~K}_{2} \mathrm{O} / \mathrm{fed}\end{array}$ & $\begin{array}{l}22.80 c \\
23.88 b \\
24.47 a\end{array}$ & $\begin{array}{l}22.47 c \\
23.52 b \\
24.00 a\end{array}$ & $\begin{array}{c}22.27 c \\
22.87 \\
23.10 b\end{array}$ \\
\hline
\end{tabular}

\section{Quality parameters:}

Results illustrated in Table (5) showed that total soluble solids and sucrose percentage were significantly increased with increasing water stress levels. On the contrary, sugar yield was lowered by deficit irrigation. Purity percentage was not significantly affected by soil moisture levels. Brown et al. (1987) observed an increase in respiration rate during the early phases of stress as a result of hydrolysis of starch to sugar. These results are in harmony with those obtained by Roberts et al. (1980), Nissen et al. (1987), Shehata et al. (2000), El-Zayat (2000) and El-Sabbagh et al. (2003).

Table (5): Mean values of root juice quality and sugar yield of sugar beet as affected by soil moisture depletion and different rates of potassium fertilizer in the combined analysis over the two growing seasons.

\begin{tabular}{|c|c|c|c|c|}
\hline Treatments & $\begin{array}{c}\text { Total soluble } \\
\text { solids (TSS\%) }\end{array}$ & $\begin{array}{c}\text { Sucrose } \\
(\%)\end{array}$ & $\begin{array}{c}\text { Purity } \\
(\%)\end{array}$ & $\begin{array}{c}\text { Sugar yield } \\
\text { (ton/fed.) }\end{array}$ \\
\hline $\begin{array}{l}\text { Irrigation treatments: } \\
40 \% \text { ASMD } \\
60 \% \text { ASMD } \\
80 \% \text { ASMD }\end{array}$ & $\begin{array}{l}20.52 \mathrm{c} \\
20.59 \mathrm{~b} \\
20.74 \mathrm{a}\end{array}$ & $\begin{array}{l}17.35 \mathrm{c} \\
17.45 \mathrm{~b} \\
17.50 \mathrm{a}\end{array}$ & $\begin{array}{l}84.55 \mathrm{a} \\
84.75 \mathrm{a} \\
84.38 \mathrm{a}\end{array}$ & $\begin{array}{c}4.12 \mathrm{a} \\
4.08 \mathrm{ab} \\
3.98 \mathrm{~b}\end{array}$ \\
\hline $\begin{array}{l}\text { K-fertilizer : } \\
\text { Control (K-0) } \\
24 \mathrm{~kg} \mathrm{~K} \mathrm{O} / \mathrm{fed} \\
48 \mathrm{~kg} \mathrm{~K}_{2} \mathrm{O} / \mathrm{fed} \\
\end{array}$ & $\begin{array}{l}20.59 \mathrm{~b} \\
20.62 \mathrm{a} \\
20.65 \mathrm{a}\end{array}$ & $\begin{array}{l}17.40 \mathrm{c} \\
17.43 \mathrm{~b} \\
17.47 \mathrm{a}\end{array}$ & $\begin{array}{l}84.51 \mathrm{a} \\
84.53 \mathrm{a} \\
84.60 \mathrm{a}\end{array}$ & $\begin{array}{l}3.92 \mathrm{c} \\
4.08 \mathrm{~b} \\
4.18 \mathrm{a}\end{array}$ \\
\hline $\begin{array}{l}\text { Interactions: } \\
\text { Irrigation } \mathrm{x} \text { season } \\
\mathrm{K} \times \text { season } \\
\text { Irrigation } \times \mathrm{K} \\
\text { Irrig. } \mathrm{x} \mathrm{K} \times \text { season }\end{array}$ & $\begin{array}{l}\text { N.S } \\
\text { N.S } \\
\text { N.S } \\
\text { N.S }\end{array}$ & $\begin{array}{l}\text { N.S } \\
\text { N.S } \\
\text { N.S } \\
\text { N.S }\end{array}$ & $\begin{array}{l}\text { N.S } \\
\text { N.S } \\
\text { N.S } \\
\text { N.S }\end{array}$ & $\begin{array}{l}\text { N.S } \\
\text { N.S } \\
\text { N.S } \\
\text { N.S }\end{array}$ \\
\hline
\end{tabular}

Means designated by the same letter at each cell are not significantly different at $5 \%$ leve according to Duncan's multiple range test.

N.S.: indicate not significant

Increasing the applied dose of potassium from zero to $48 \mathrm{~kg} \mathrm{~K} 2 \mathrm{O} / \mathrm{fed}$. significantly increased total soluble solids, sucrose percentage and sugar yield. On the other hand, purity percentage was not significantly influenced by K-rates. The appreciable effect of increasing the applied K-levels on sugar 
yield could be attributed to the beneficial influence of potassium on root fresh weight/plant, sucrose $\%$, purity $\%$ and root and sugar yields. This result coincides with that obtained by Basha (1994), and El-Shafai (2000). All the interactions failed to exert any significant effects on the studied characters.

III. Soil-water relations:

1. Water consumptive use (WCU):

Mean values of water consumptive use as affected by soil moisture levels and different rates of potassium fertilizer are presented in Table (6).

Seasonal water consumptive use was increased as a result of higher frequent irrigation due to irrigation after $40 \%$ of ASMD than irrigation after $60 \%$ and $80 \%$ of ASMD. This trend showed that the increment in water consumptive use depends on the availability of soil moisture in the root zone. Doorenbos and Pruitt (1977) gave an extensive explanation of the effect of available soil water on evapotranspiration, they stated that after irrigation or rain the water content will be reduced primarily by evapotranspiration. As the soil was dried, the rate of water transmitted through the soil will reduce. The effect of soil water content on evapotranspiration varies with crop and soil type, as well as water holding characteristics. Carter et al. (1980) showed that limited irrigation reduced evapotranspiration rates because of drier surface soil and partial stomatal closure, thereby decreasing the rate of water extraction from the soil reservoir by the plant. These results were supported by the data obtained by Shams El-Din (2000) and El-Zayat (2000) and ElSabbagh et al. (2003).

Table (6): Monthly and seasonal water consumptive use of sugar beet as affected by available soil moisture depletion and different rates of potassium fertilizer (average the two seasons).

\begin{tabular}{|c|c|c|c|c|c|c|c|c|c|}
\hline \multirow{2}{*}{$\begin{array}{l}\text { Irrigation } \\
\text { treatments }\end{array}$} & \multirow{2}{*}{$\begin{array}{c}\text { Potassium } \\
\text { fertilizer } \\
\text { (kg K } \mathrm{K}_{2} \mathrm{O} / \mathrm{fed} \text {.) }\end{array}$} & \multicolumn{7}{|c|}{ Monthly rates $(\mathrm{cm})$} & \multirow{2}{*}{$\begin{array}{c}\text { Seasonal } \\
\text { rates } \\
(\mathrm{cm})\end{array}$} \\
\hline & & Nov. & Dec. & Jan. & Feb. & Mar. & Apr. & May & \\
\hline \multirow{3}{*}{$\begin{array}{l}40 \% \\
\text { ASMD }\end{array}$} & 0 & 1.77 & 4.63 & 6.27 & 8.52 & 13.21 & 16.15 & 9.90 & 60.45 \\
\hline & 24 & 1.77 & 4.63 & 6.32 & 8.62 & 13.35 & 16.20 & 9.95 & 60.84 \\
\hline & 48 & 1.77 & 4.63 & 6.42 & 8.79 & 13.71 & 16.32 & 10.06 & 61.70 \\
\hline \multicolumn{2}{|c|}{ Mean } & 1.77 & 4.63 & 6.43 & 8.64 & 13.43 & 16.22 & 9.97 & 61.00 \\
\hline \multirow{3}{*}{$\begin{array}{l}60 \% \\
\text { ASMD }\end{array}$} & 0 & 1.77 & 4.63 & 5.74 & 7.73 & 11.68 & 14.67 & 9.02 & 55.24 \\
\hline & 24 & 1.77 & 4.63 & 6.77 & 7.76 & 11.76 & 14.70 & 9.06 & 56.45 \\
\hline & 48 & 1.77 & 4.63 & 6.87 & 7.87 & 11.81 & 14.76 & 9.17 & 56.88 \\
\hline \multicolumn{2}{|c|}{ Mean } & 1.90 & 4.63 & 5.79 & 7.79 & 11.76 & 14.71 & 9.08 & 56.19 \\
\hline \multirow{3}{*}{$\begin{array}{l}80 \% \\
\text { ASMD }\end{array}$} & 0 & 1.77 & 4.63 & 4.57 & 5.80 & 9.76 & 12.70 & 6.55 & 45.78 \\
\hline & 24 & 1.77 & 4.63 & 4.67 & 5.92 & 10.02 & 12.77 & 6.74 & 46.52 \\
\hline & 48 & 1.77 & 4.63 & 4.72 & 6.02 & 10.06 & 12.80 & 6.84 & 46.84 \\
\hline \multicolumn{2}{|c|}{ Mean } & 1.77 & 4.63 & 4.65 & 5.91 & 9.95 & 12.76 & 6.71 & 46.38 \\
\hline \multicolumn{5}{|c|}{ Total potassium average $(\mathrm{cm}) \mathrm{K}-0=53.82$} & & $4=54.6$ & & $-48=$ & .15 \\
\hline
\end{tabular}

Respecting to the effect of K-rates application, data showed a slight increase in seasonal water use as K-rates increased. Such increase in evapotranspiration rate following potassium application may be due to the enhancing effect of K-fertilizer on growth which resulted in an increase in plant canopy thereby increasing the transpiring surface and that reflected on seasonal water use. The above results were in line with those reported by ElSabbagh et al. (2003) who found an increase in water consumptive use of sugar beet plants by increasing $\mathrm{K}_{2} \mathrm{O}$ from zero to $48 \mathrm{~kg} / \mathrm{fed}$. 


\section{Irrigation water requirements (IWR):}

Table 7 indicated that irrigating sugar beet plants at $40 \%$ ASMD resulted in the highest amount of water applied to be $68.28 \mathrm{~cm}(2867.8$ $\mathrm{m}^{3} / \mathrm{fed}$.), distributed on eight irrigations, followed by irrigation at $60 \%$ of ASMD to be $62.08 \mathrm{~cm}$ (2607.4 $\mathrm{m}^{3} / \mathrm{fed}$.), distributed on seven irrigations and irrigation at $80 \%$ of ASMD to be $55.07 \mathrm{~cm}\left(2312.9 \mathrm{~m}^{3} / \mathrm{fed}\right.$.), distributed on six irrigations, respectively. Planting irrigation and the first irrigation were the same for all irrigation treatments. The average of the effective rainfall was 5.8 $\mathrm{cm}$ over both growing seasons. It is obvious that amount of irrigation water applied was gradually increased as a result of growing up of a vegetative growth that required higher amount of irrigation water to meet its water requirements, and then it decreased again. These findings maybe attributed to growth stages, and the availability of soil water content in the root zone.

Table (7):Amounts of seasonal irrigation water applied $(\mathrm{cm})$ as affected by the different irrigation treatments, as well as the amounts of effective rainfall (cm), over both seasons.

\begin{tabular}{|c|c|c|c|}
\hline \multirow{2}{*}{ Variables } & \multicolumn{3}{|c|}{ Irrigation treatments } \\
\hline & $40 \%$ ASMD & $60 \%$ ASMD & $80 \%$ ASMD \\
\hline Planting irrigation & $10.05 \mathrm{~cm}$ & $10.05 \mathrm{~cm}$ & $10.05 \mathrm{~cm}$ \\
\hline & (422.1 m³/fed.) & (422.1 $\mathrm{m}^{3} /$ fed.) & (422.1 m³/fed.) \\
\hline $1^{\text {st }}$ irrigation & $7.86 \mathrm{~cm}$ & $7.86 \mathrm{~cm}$ & $7.86 \mathrm{~cm}$ \\
\hline & (330.1 m³/fed.) & (330.1 m³/fed.) & (330.1 m³/fed.) \\
\hline $2^{\text {nd }}$ irrigation & $8.19 \mathrm{~cm}$ & $8.67 \mathrm{~cm}$ & $8.95 \mathrm{~cm}$ \\
\hline & (344.0 m³/fed.) & (364.1 m³/fed.) & (375.9 m³/fed.) \\
\hline $3^{\text {rd }}$ irrigation & $8.69 \mathrm{~cm}$ & $8.90 \mathrm{~cm}$ & $9.24 \mathrm{~cm}$ \\
\hline & (365.0 m³/fed.) & (373.8m³/fed.) & (388.1 m³/fed.) \\
\hline $4^{\text {th }}$ irrigation & $\begin{array}{c}9.08 \mathrm{~cm} \\
\left(381.4 \mathrm{~m}^{3} / \mathrm{fed}\right)\end{array}$ & $\begin{array}{c}9.32 \mathrm{~cm} \\
\left(3914 \mathrm{~m}^{3} / \mathrm{fed}\right)\end{array}$ & $\begin{array}{c}9.86 \mathrm{~cm} \\
\left(4141 \mathrm{~m}^{3} / \mathrm{fed}\right)\end{array}$ \\
\hline $5^{\text {th }}$ irrigation & $8.42 \mathrm{~cm}$ & $8.80 \mathrm{~cm}$ & $9.11 \mathrm{~cm}$ \\
\hline & (353.6 m³/fed.) & (369.6 m³/fed.) & (382.6 m³/fed.) \\
\hline $6^{\text {th }}$ irrigation & $8.11 \mathrm{~cm}$ & $8.48 \mathrm{~cm}$ & \\
\hline & (340.6 m³/fed.) & (356.2 $\mathrm{m}^{3} /$ fed.) & \\
\hline $7^{\text {th }}$ irrigation & $\begin{array}{c}7.88 \mathrm{~cm} \\
\left.\text { (331.0 } \mathrm{m}^{3} / \mathrm{fed} .\right)\end{array}$ & & \\
\hline Irrigation water applied & $\begin{array}{c}68.28 \mathrm{~cm} \\
\left(2867.8 \mathrm{~m}^{3} / \text { fed. }\right)\end{array}$ & $\begin{array}{c}62.08 \mathrm{~cm} \\
\left(2607.4 \mathrm{~m}^{3} / \mathrm{fed} .\right)\end{array}$ & $\begin{array}{c}55.07 \mathrm{~cm} \\
\left(2312.9 \mathrm{~m}^{3} / \mathrm{fed} .\right)\end{array}$ \\
\hline Effective rainfall* & $\begin{array}{c}5.80 \mathrm{~cm} \\
\left(244.0 \mathrm{~m}^{3} / \mathrm{fed} .\right)\end{array}$ & $\begin{array}{c}5.80 \mathrm{~cm} \\
\left(244.0 \mathrm{~m}^{3} / \mathrm{fed} .\right)\end{array}$ & $\begin{array}{c}5.80 \mathrm{~cm} \\
\left(1559.5 \mathrm{~m}^{3} / \mathrm{fed} .\right)\end{array}$ \\
\hline $\begin{array}{l}\text { Irrigation water } \\
\text { requirements (IWR) }\end{array}$ & $\begin{array}{c}74.08 \mathrm{~cm} \\
\left(3111.4 \mathrm{~m}^{3} / \mathrm{fed} .\right)\end{array}$ & $\begin{array}{c}67.88 \mathrm{~cm} \\
\left(2851.4 \mathrm{~m}^{3} / \mathrm{fed} .\right)\end{array}$ & $\begin{array}{c}60.87 \mathrm{~cm} \\
\left(2556.9 \mathrm{~m}^{3} / \mathrm{fed} .\right)\end{array}$ \\
\hline
\end{tabular}

\section{Crop water use efficiency (CWUE):}

Water use efficiency by sugar beet expressed as $\mathrm{kg}$ roots or sugar yield produced $/ \mathrm{cm}$ of water consumed as affected by irrigation regime and potassium fertilizer is presented in Table 8.

Data showed that irrigation after $80 \%$ of ASMD resulted in the highest CWUE for both root and sugar yields, while it was lower under $40 \%$ of ASMD. These results could be attributed to the high significant differences in the roots or sugar yield production as well as the differences between the water consumptive uses. These results are in agreement with those obtained by Shams El-Din (2000), Saied (2000), El-Zayat (2000), El-Sabbagh et al. (2003) and Abou Ahmed (2003). 
Regarding the effect of potassium, CWUE for both root or sugar yields was increased with increasing potassium rate. This finding could be related to higher yield more than the increase in water consumed by sugar beet. The previous results are in line with those reported by Welch and Flannery (1985), and El-Sabbagh et al., (2003) who concluded that potassium supply increased CWUE of sugar beet and corn plants.

Table (8): Crop water use efficiency by sugar beet in $\mathrm{kg}$ root and sugar yield $/ \mathbf{c m}$ of water consumed as affected by soil moisture depletion and different rates of potassium fertilizer in the combined analysis over the two growing seasons.

\begin{tabular}{|c|c|c|c|c|}
\hline \multirow{2}{*}{\begin{tabular}{|l|} 
Irrigation \\
treatments
\end{tabular}} & \multicolumn{3}{|c|}{ CWUE (kg root yield/cm of water consumed) } & \multirow[t]{2}{*}{ Mean } \\
\hline & $40 \%$ SMD & $60 \%$ SMD & $80 \%$ SMD & \\
\hline $\begin{array}{l}\text { K-fertilizer : } \\
\text { Control (K-0) } \\
24 \text { kg K2O/fed } \\
48 \text { kg K }{ }_{2} \mathrm{O} / \mathrm{fed} \\
\end{array}$ & $\begin{array}{c}\text { 377.2e } \\
\text { 392.6de } \\
\text { 396.5de }\end{array}$ & $\begin{array}{c}406.7 d \\
416.6 c d \\
425.5 c\end{array}$ & $\begin{array}{l}486.4 \mathrm{~b} \\
491.5 \mathrm{a} \\
493.1 \mathrm{a}\end{array}$ & $\begin{array}{l}423.4 \mathrm{C} \\
433.6 \mathrm{~B} \\
438.4 \mathrm{~A}\end{array}$ \\
\hline \multirow[t]{2}{*}{ Mean } & $388.8 \mathrm{C}$ & 416.3B & $490.3 \mathrm{~A}$ & \\
\hline & \multicolumn{3}{|c|}{ CWUE (kg sugar yield/cm of water consumed) } & Mean \\
\hline $\begin{array}{l}\text { K-fertilizer : } \\
\text { Control (K-0) } \\
24 \mathrm{~kg} \mathrm{~K} 2 \mathrm{O} / \mathrm{fed} \\
48 \mathrm{~kg} \mathrm{~K} \mathrm{~K}_{2} \mathrm{O} / \mathrm{fed} \\
\end{array}$ & $\begin{array}{c}65.84 \mathrm{~g} \\
68.72 \mathrm{fg} \\
69.57 \mathrm{f}\end{array}$ & $\begin{array}{l}70.80 \mathrm{e} \\
72.67 \mathrm{~d} \\
74.43 \mathrm{c}\end{array}$ & $\begin{array}{l}84.27 b \\
85.23 a \\
85.65 a\end{array}$ & $\begin{array}{l}73.64 \mathrm{C} \\
75.54 \mathrm{~B} \\
76.55 \mathrm{~A}\end{array}$ \\
\hline Mean & $68.04 \mathrm{C}$ & $72.63 \mathrm{~B}$ & $85.05 \mathrm{~A}$ & \\
\hline
\end{tabular}

Means designated by the same letter at each cell are not significantly different at $5 \%$ level according to Duncan's multiple range test.

\section{Field water use efficiency (FWUE):}

Data in Table 9 indicated that irrigation at $80 \%$ of ASMD increased FWUE ( $\mathrm{kg}$ root and sugar yield/cm of water applied) compared to irrigation at $60 \%$ and $40 \%$ of ASMD, respectively. El-Sabbagh et al. (2003) indicated that water utilization efficiency increased with increasing in soil moisture stress. Applying potassium fertilizer at rate of $48 \mathrm{~kg} \mathrm{~K} \mathrm{~K}_{2} \mathrm{O} / \mathrm{fed}$. increased FWUE compared to the treatments received $24, \mathrm{~K}_{2} \mathrm{O} / \mathrm{fed}$. and the control, respectively.

The interaction between irrigation and potassium rates in Tables 8 and 9 showed that higher value of water use efficiencies was obtained from irrigation at $80 \%$ of $\mathrm{ASMD}$ with $48 \mathrm{~kg} \mathrm{~K} \mathrm{~K}_{2} \mathrm{O} / \mathrm{fed}$. On the other hand, irrigation at $40 \%$ of ASMD with control treatment resulted in lower water use efficiencies. 
Table (9): Field water use efficiency by sugar beet in $\mathrm{kg}$ root and sugar yield/cm of water applied as affected by soil moisture depletion and different rates of potassium fertilizer in the combined analysis over the two growing seasons.

\begin{tabular}{|c|c|c|c|c|}
\hline \multirow{2}{*}{\begin{tabular}{|l} 
Irrigation \\
treatments
\end{tabular}} & \multicolumn{3}{|c|}{ FWUE (kg root yield/cm of water applied) } & \multirow{2}{*}{ Mean } \\
\hline & $40 \%$ ASMD & $60 \%$ ASMD & $80 \%$ ASMD & \\
\hline \multicolumn{5}{|l|}{\begin{tabular}{|l} 
K-fertilizer: \\
\end{tabular}} \\
\hline Control (K-0) & $307.8 \mathrm{~h}$ & $331.0 \mathrm{e}$ & $365.8 b$ & $334.9 \mathrm{C}$ \\
\hline $24 \mathrm{~kg} \mathrm{~K} 2 \mathrm{O} / \mathrm{fed}$ & $322.4 \mathrm{~g}$ & $346.4 d$ & $375.7 a$ & $348.2 B$ \\
\hline $48 \mathrm{~kg} \mathrm{~K} \mathrm{~K}_{2} \mathrm{O} / \mathrm{fed}$ & $330.3 f$ & $356.5 \mathrm{c}$ & $379.4 a$ & $355.4 \mathrm{~A}$ \\
\hline \multirow[t]{2}{*}{ Mean } & $320.4 \mathrm{C}$ & $344.6 \mathrm{~B}$ & $373.6 \mathrm{~A}$ & \\
\hline & \multicolumn{3}{|c|}{ FWUE (kg sugar yield/cm of water applied) } & Mean \\
\hline K-fertilizer: & & & & \\
\hline Control (K-0) & $53.73 \mathrm{~g}$ & $57.61 \mathrm{e}$ & $63.38 b$ & $58.24 \mathrm{C}$ \\
\hline $24 \mathrm{~kg} \mathrm{~K} 2 \mathrm{O} / \mathrm{fed}$ & $56.44 f$ & $60.43 d$ & $65.14 a$ & $60.67 \mathrm{~B}$ \\
\hline $48 \mathrm{~kg} \mathrm{~K}{ }_{2} \mathrm{O} / \mathrm{fed}$ & 57.94 ef & $62.37 \mathrm{c}$ & $65.91 \mathrm{a}$ & $62.07 \mathrm{~A}$ \\
\hline Mean & $56.04 C$ & $60.14 \mathrm{~B}$ & $64.81 \mathrm{~A}$ & \\
\hline
\end{tabular}

Means designed by the same letter at each cell are not significantly different at $5 \%$ level according to Duncan's multiple range test.

\section{Soil moisture extraction pattern (SMEP):}

Data of mean values of soil moisture extraction percentage in the upper $60 \mathrm{~cm}$ soil depth as affected by soil moisture depletion and potassium fertilizer are presented in Table (10).

Results indicated that the highest percentage of moisture uptake was occurred at the surface layer $15 \mathrm{~cm}$ of the soil profile. Less water was extracted from the successive depths. The mean percentage values of water extracted from the upper $30 \mathrm{~cm}$ soil layer were 76.36, 71.78 and $65.18 \%$ when irrigated at $40 \%, 60 \%$ and $80 \%$ of ASMD, respectively, while the respective values were $23.64 \%, 28.22 \%$ and $34.82 \%$ withdrawn from the lower $30-60 \mathrm{~cm}$.

Table (10): Percentage of water uptake by sugar beet roots from soil layers as affected by soil moisture depletion and potassium fertilizer (average the two seasons).

\begin{tabular}{|c|c|c|c|c|c|c|c|}
\hline \multirow{2}{*}{$\begin{array}{l}\text { Irrigation } \\
\text { treatments }\end{array}$} & \multirow{2}{*}{$\begin{array}{c}\text { K-rates } \\
\text { kg } \\
\left(\mathrm{K}_{2} \mathrm{O} / \mathrm{fed} .\right)\end{array}$} & \multicolumn{4}{|c|}{ Soil depth(cm) } & \multicolumn{2}{|c|}{$\begin{array}{c}\text { Average moisture } \\
\text { extraction }\end{array}$} \\
\hline & & $0-15$ & $15-30$ & $30-45$ & $45-60$ & $0-30$ & $30-60$ \\
\hline \multirow[t]{3}{*}{$40 \%$ ASMD } & 0 & 47.65 & 28.20 & 18.70 & 5.45 & 75.85 & 24.15 \\
\hline & 24 & 47.91 & 28.49 & 18.82 & 4.78 & 76.40 & 23.60 \\
\hline & 48 & 48.11 & 28.73 & 18.85 & 4.41 & 76.84 & 23.16 \\
\hline \multicolumn{2}{|l|}{ Mean } & 47.89 & 28.51 & 18.79 & 4.81 & 76.36 & 23.64 \\
\hline \multirow[t]{3}{*}{$60 \%$ ASMD } & 0 & 44.37 & 27.02 & 20.2 & 8.41 & 71.39 & 28.61 \\
\hline & 24 & 44.63 & 27.25 & 20.62 & 7.50 & 71.88 & 28.12 \\
\hline & 48 & 44.70 & 27.38 & 20.69 & 7.23 & 72.08 & 27.92 \\
\hline \multicolumn{2}{|l|}{ Mean } & 44.57 & 27.23 & 20.50 & 7.71 & 71.78 & 28.22 \\
\hline \multirow[t]{3}{*}{$80 \% A$ SMD } & 0 & 39.38 & 25.40 & 22.75 & 12.47 & 64.78 & 35.22 \\
\hline & 24 & 39.61 & 25.66 & 22.92 & 11.81 & 65.27 & 34.73 \\
\hline & 48 & 39.75 & 25.74 & 22.98 & 11.53 & 65.49 & 34.51 \\
\hline \multicolumn{2}{|l|}{ Mean } & 39.58 & 25.60 & 22.88 & 11.94 & 65.18 & 34.82 \\
\hline
\end{tabular}


These findings could be attributed to the fact that most of plant roots are concentrated in the upper soil layers and those are the most effective in water extraction. The same results were found by Mitchell and Rusell (1971), and Abou Ahmed (2003) who reported that a relatively high water uptake from the top layers occurred compared to deep layers, as a result of the concentration roots in the upper layers. For potassium fertilizer, results showed that no obvious effect on the removal moisture.

6. Regression slopes and correlation coefficients:

A linear equation is presented in Table 11 indicated that each one $\mathrm{cm}$ of water applied increased the productivity of roots and sugar yield by 74 and $15.7 \mathrm{~kg} / \mathrm{fed}$. as shown in Eq. [1 and 2]. It means hat both root and sugar yields were improved with increasing water consumption. However, each one $\mathrm{cm}$ of water applied decreased crop water use efficiency (CWUE) by $7.8 \mathrm{~kg}$ root yield/cm of water consumed (Eq. [3]) and decreased field water use efficiency (FWUE) by $4.1 \mathrm{~kg} /$ root of water applied (Eq. [4]). Irrigation water applied is strongly positively correlated with roots and sugar yields and negatively to water use efficiencies as shown in Table 11. The positive correlation indicted that sugar yield increases when root and sugar yields and water consumptive use increase due to irrigation water applied. In this concern, Ghanem and Gomma (1985), and El-Sabbagh et al. (2001) found that sugar yield was positively and significantly correlated with root yield.

Table (11): Regression slopes and correlation coefficients between irrigation water applied (IWR) and root yield (RY), sugar yield (SY), crop water use efficiency (CWUE) and field water use efficiency (FWUE).

\begin{tabular}{|l|c|c|}
\hline Variables & Equation & Correlation (r) \\
\hline IWR & $\dot{Y}=18275+74(\mathrm{RY}) . .[1]$ & $0.65^{\star}$ \\
\hline IWR & $\dot{Y}=2998+15.7(\mathrm{SY}) . .[2]$ & $0.67^{*}$ \\
\hline IWR & $\dot{Y}=956-7.8 \mathrm{CWUE..[3]}$ & -0.72 \\
\hline IWR & $\dot{Y}=620-4.1$ FWUE..[4] & -0.69 \\
\hline
\end{tabular}

\section{REFERENCES}

Abou-Ahmed, Ei-Sh.l. 2003. Effect of irrigation intervals and nitrogen fertilization on the productivity of sugar beet crop. J. Agric., Tanta Univ., 29(4):736-745.

Basha, H.A. 1994. Influence of potassium fertilizer level on yield and quality of some beet cultivars in newly cultivated sandy soil. Zagazig. J. Agric. Res. 21(6): 1631-1644.

Black, C.A.; D.D. Evans; L.E. Ensminger; J.L. White and F.E. Clark. 1985. Methods of Soil Analysis. Am. Soc. of Agronomy, Inc., Madison Wisconsin, U.S.A. Library of Congress Catalog Card Number; 6515800 Seventh Printing.

Brown, K.F.; A.B. Messem; R.J. Dunham and P.V. Biscoe. 1987. Effect of drought on growth and water use of sugar beet. J. Agric. Sci., 109(3): 421-436. 
Carter, J.M.; M.E. Jensen and D.J. Traveller. 1980. Effect of mid to late season water stress on sugar beet growth and yield. Agron. J, 72(5): 806-815.

Doorenbos, J. and W.O. Pruitt. 1977. Guidelines for predicting crop water requirements. Irrigation and Drainage, paper No. 24, FAO, Rome. Italy.

Duncan, B.D. 1955. Multiple range and multiple F. test. Biometrics. 11: 1-42.

El-Essawy, I.I. 1996. Effect of nitrogen, phosphorus and potassium fertilizers on yield and quality of sugar beet. Tanta J. Agric. Res. 22(2): 270-278.

El-Sabbagh, A.A, S.A. Abd El-Hafez, A.Z. El-Bably and E.I. Abou-Ahmed. 2003. Sugar beet productivity as affected by soil moisture depletion levels and potassium fertilization. Minufiya J. Agric. Res. 28(2) 527546.

El-Shafai, A.M.A. 2000. Effect of nitrogen and potassium fertilization on yield and quality of sugar beet in Sohag. Egypt J. Agric. Res. 78(2): 759-767.

El-Zayat, M.M.T. 2000. Effect of irrigation regime and fertilization on sugar beet. Ph.D. Thesis Fac. of Agric. Kafr El-Sheikh Tanta Univ., Egypt.

Gaber, A.A.; M.M. El-Banna and A.H. Nour. 1986. Effect of irrigation intervals and nitrogen levels on yield of sugar beet. Alex. Sci. Exch. 7 No. 4, 1986.

Ghanem, S.A. and A.S. Gomma. 1985. The influence of nitrogen fertilization and growth regulators on yield and quality of sugar beet. Zagazig, J. Agric. Res. Vol. 2: 229-252.

Hansen, V.W.; O.W. Israelsen and G.E. Stringhram. 1979. Irrigation principle and practices. $4^{\text {th }}$ Edition, John Wiley and Sons, New York.

Hills, F.S.; S.S. Johnson and B.A. Godwin. 1990. The sugar beet industry. California Univ., Exp. Stn. Bull. 1916 (C.F. Irrigation of Agricultural Crops, 5613, 1742, 1990).

Jensen, M.E. (1983). Design and operation of farm irrigation systems. Amer. Soc. Agric. Eng. Michigan, USA.

Khalifa, M.R.; A.A. Balba; S.A. Mashali and S.A. Morsi. 2000. Impact of soil ploughing depth and different rates of NPK fertilizers on some soil properties, yield and quality of sugar beet plant grown in salt affected soil. J. Agric. Res. Tanta Univ. 26(1): 108-121.

Khalil, S.M.; S.N. Mostafa and Z.R. Mostafa. 2001. Influence of potassium fertilizer and soil salinity on chemical composition of sugar beet root. Minufiya J. Agric. Res. Vol. 26, No. 3: 583-594.

Le-Docte, A. 1927. Commercial determination of sugar in beet root using the sachs. LeDocte process. Int. Sug. J. 29: 488-492.

Michael, A.M. 1978. Irrigation theory and practice. Vikas Publishing House PVTLTD New Delhi, Bombay.

Mitchell, R.L. and W.J. Rusell. 1971. Root development and rooting patterns of soybean. Agron. J. 63: 313-316.

Nissen, M.J.; T.H. Vargas and P.R. Daroch. 1987. Effect of irrigation on yield and sucrose content of sugar beet (Beta vulgaris L. var. Saccharifera) under two fertilization regime in Osorno. Chile Agro. Sur., 15(1): 19-25 (C.F. Irrigation and Drainage Abst. 14: 1335, 1988).

Novica, V. (1979). Irrigation of agriculture crops. Fac. Agric. Press, Novi Sad, Yugoslavia.

Roberts, S.; J.E. Middleton; A.W. Richards; W.H. Weaver and L.F. Hall. 1980. Sugar beet production under centerpivot irrigation with different rates of nitrogen. Bulletin, College of Agric. Res. Cent. Washington State Univ. 884: $5 \mathrm{pp}$.

Saied, M.M. 2000. Effect of irrigation intervals, furrow irrigation system and nitrogen fertilizer levels on sugar beet yield and it's water relations at North Delta. J. agric. Sci. Mansoura Univ., 25(7):4737-4745. 
Saif, Laila, M.; S.S. Zaiat and I.H. El-Gaddawy. 1997. Effect of holding irrigation intervals and harvesting dates on yield and its attributes of sugar beet. Mansoura J. Agric. Res. 22(2): 341-347.

Selim, A.F.H. and Fatma, H. El-Ghinbihi. 1999. Studies on sugar beet plants (Beta vulgaris L.) cv. Raspoly as affected by NPK nutrients in sand cultures. Minufiya J. Agric. Res., 24(6): 1819-1849.

Semaika, M. and A. Hady Rady. 1988. Factors affecting crop coefficient when calculating crop evapotranspiration. IAHS-Publication. 169: 175-184 (C.F. Soils and Fertilizers, 52: 8688, 1989).

Shams El-Din, H.A. 2000. Effect of water application levels and different wetting depths on sugar beet yield and its water relations at North Delta. J. Agric. Sci. Mansoura Univ., 25(9): 5931-5939.

Shehata, Mona, M.; Sohair, A.A. and Shafika, N.M. 2000. The effect of soil moisture stress on some sugar beet varieties. Egypt J. Agric. res. 78(3): $1141-1160$

Simpson, G.M. 1981. Water stress on plants. CBS Educational and professional Publishing, New York, U.S.A.

Snedecor, G.W. and W.G. Cochran. 1980. Statistical Methods 7th Edition, lowa State Univ. Press, Ames, lowa, U.S.A.

Welch, L.F. and R.L. Flannery. 1985. Potassium nutrition of corn. Potassium in Agriculture. Proceedings of an International Symposium held 7-10 July in Atlanta and Georgia, Edited by R. Munson, 647-663.

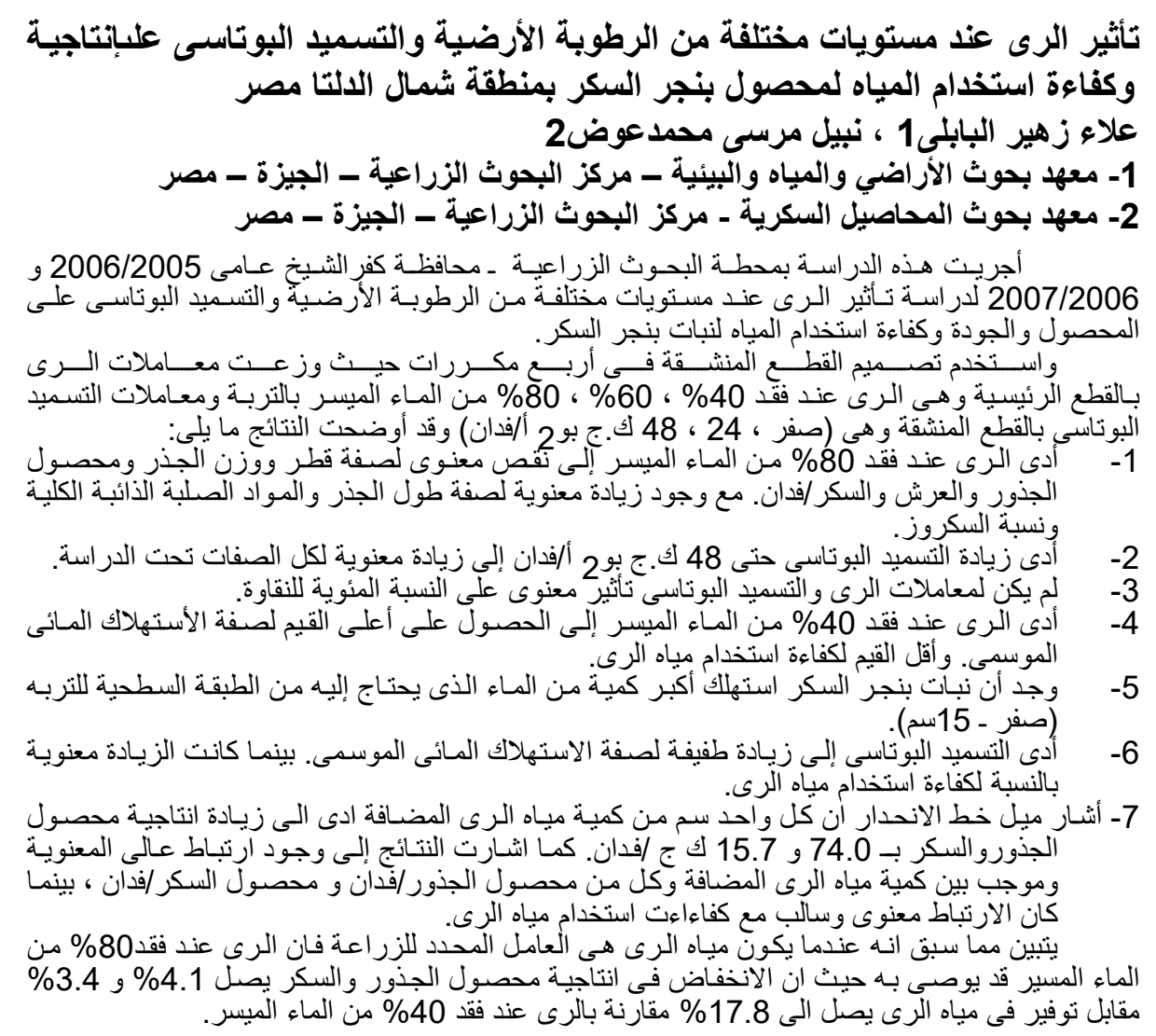

